\title{
Putjata's expedition to Chinese Khingan in 1891 and its small mammal collection from "Tongjia Yingzi" kept at the Zoological Institute in St. Petersburg, Russia
}

\author{
Leonid L. Voyta*, Fedor N. Golenishchev \& Ekaterina A. Petrova
}

\begin{abstract}
All available information on the small mammal collection from the collecting point Tongjia Yingzi of the Khingan expedition in 1891 under the leadership by Dmitry V. Putjata is presented. Also, the geographic position of this point is clarified. The collection is kept at the Zoological Institute of the Russian Academy of Sciences (St. Petersburg, Russia) and, at present, contains 17 specimens from Tongjia Yingzi of Putjata's Khingan collection; these belong to Lipotyphla, Chiroptera, and Rodentia.

How to cite this article: Voyta L.L., Golenishchev F.N., Petrova E.A. 2019. Putjata's expedition to Chinese Khingan in 1891 and its small mammal collection from "Tongjia Yingzi" kept at the Zoological Institute in St. Petersburg, Russia //Russian J. Theriol. Vol.18. No.1. P.56-66. doi: 10.15298/rusjtheriol.18.1.07.
\end{abstract}

KEY WORDS: Zoological Institute Mammals Collection, Dmitry V. Putjata, Great Khingan Range, Lipotyphla, Chiroptera, Rodentia.

Leonid L.Voyta [leonid.voyta@zin.ru], Fedor N. Golenishchev [fedor.golenishchev@zin.ru], Ekaterina A. Petrova [ekaterina.petrova@zin.ru], Zoological Institute, Russian Academy of Sciences, Universitetskaya nab. 1, Saint Petersburg 199034, Russia.

\section{Коллекция мелких млекопитающих из «Тунцзя-инцза», собранных экспедицией Путяты 1891 г. в китайском Хингане, хранящаяся в Зоологическом институте РАН (Санкт-Петербург, Россия)}

\begin{abstract}
Л.Л. Войта*, Ф.Н. Голенищев, Е.А Петрова
РЕЗЮМЕ. Приведена вся доступная информация о мелких млекопитающих, собранных в 1891 г. экспедицией Д.В. Путяты по Хингану из точки сбора материала «Тунцзя-инцза», а также уточнено ее географическое положение. В настоящее время в Зоологическом институте РАН (Санкт-Петербург, Россия) хранится 17 экземпляров из точки «Тунцзя-инцза» хинганских сборов Д.В. Путяты, которые принадлежат отрядам Lipotyphla, Chiroptera и Rodentia.
\end{abstract}

КЛЮЧЕВЫЕ СЛОВА: Коллекция млекопитающих Зоологического института, Дмитрий Васильевич Путята, хребет Большой Хинган, Lipotyphla, Chiroptera, Rodentia.

\section{Introduction}

The mammalian collection of the Zoological Institute of the Russian Academy of Sciences (Saint Petersburg, Russia) originates from collections of the Kunstkamera, which were transferred to the Zoological Museum of Imperial Academy of Sciences after 1832 (Strauch, 1889). Since that time, the vertebrate collection has been constantly replenished from expedition materials, such as from the travels of Karl M. Baer (Novaja Zemlja in 1837; Lapland in 1840), Ilia G. Voznesensky (Siberia, America in 1839-1849), Alexander F. Middendorff (Siberia in 1842-1845), Leopold I. Schrenck (Far East in 1853-1856), Ivan S. Poljakov (Siberia in 1876; Semiretchinskaja Oblast' in 1877; Sakhalin Isl. in 1881), and many other zoologists (Strauch, 1889). In this

\footnotetext{
* Corresponding author.
}

view, one of the most notable expeditions were a series of Great Asian expeditions of Nikolay M. Przhevalsky, who conducted four large field trips between 1870 and 1886 (Przhevalsky, 1897). After Przhevalsky dead during the subsequent expedition in 1888, his followers - Mikhail V. Pevtsov, Vsevolod B. Roborovsky, Petr K. Kozlov (Kozlov, 1948), together with several other persons - continued the study of East and Inner Asia and significantly increased mammalian collections of the Zoological Museum. Dmitry V. Putjata was not a participant in Przhevalsky's expeditions but organized a Chinese expedition to investigate nature and people of the south part of the Great Khingan Range in 1891, and collected botanical and zoological materials (Putjata, 1893) which were taken as the basis for the description of several new taxa.

The majority of labels, tied to specimens, collected during the second half of the $19^{\text {th }}$ and beginning of the 
$20^{\text {th }}$ centuries, contained very brief locality explanations, such as "Kun-Lun". Most specimens from Putjata's expedition were marked as Tongjia Yingzi (in Russian as “Тунцзя-[и]Инцза", “Тунзця-[и]Инцза") and "Southern Khingan". Thus, there were no clear, exact localities on any of field labels originated from Putjata expedition. These vague localities were used in the descriptions of a new species of hedgehog (Erinaceus chinensis Satunin, 1907) and mole (Parascaptor grandidens Stroganov, 1941). Correct determination of a geographical position for Tongjia Yingzi gives us the possibility of describing more precisely the distribution range of mammals. Therefore, the current paper aims to clarify geographic and taxonomic information on mammalian specimens collected by Khingan expedition of 1891 from Tongjia Yingzi and kept in the Zoological Institute of Saint Petersburg.

\section{Material and methods}

All described specimens are kept in a collection of the Laboratory of Theriology of the Zoological Institute of the Russian Academy of Sciences (St. Petersburg, Russia). Photographs of skulls and dentaries were made using digital camera Canon EOS 60D. The maps were prepared using vector layers from digital resources: ESRI (http://www.esri.com/), Google (https://www.google.ru/ maps/), and military maps using SASPlanet software (v.160707.9476).

Abbreviations. $\mathrm{CBL}=$ condylobasal length; $\mathrm{EL}=$ ear length; $\mathrm{HB}=$ head and body length; $\mathrm{HL}=$ hindfoot length; $\mathrm{MRH}=$ mandibular ramus height; $\mathrm{SCL}=$ skull common length; TL = tail length; $\mathrm{ZIN}=$ the Zoological Institute of the Russian Academy of Sciences.

\section{The geographic position of Tongjia Yingzi}

The route of the Khingan expedition of Dmitry V. Putjata was published in 1893 (Putjata, 1893). The locality names and the map are presented in Putjata's diary in Russian, and most of them cannot be found on maps available. However, several geographic names could be associated with modern locations and were used therefore for comparison the route with a modern map (Fig. 1).

Table 1. Association between the name of localities and rivers from Putjata's map and modern names within Chinese territory, with coordinates

\begin{tabular}{|c|c|c|c|}
\hline nn & $\begin{array}{c}\text { Original names from } \\
\text { the map }\end{array}$ & Modern names & Coordinates \\
\hline 01 & Тянь-Цзинь & Tianjin City (Tianjin Municipality) & $\mathrm{N} 39.13389^{\circ} \mathrm{E} 117.18806^{\circ}$ \\
\hline 02 & Ханькоу & $\begin{array}{l}\text { Hangu District, Tianjin (Tianjin } \\
\text { Municipality) }\end{array}$ & $\mathrm{N} 39.23722^{\circ} \mathrm{E} 117.80333^{\circ}$ \\
\hline 03 & Цзун-хуа-чжоу & $\begin{array}{c}\text { Zunhua county-level city (Tangshan Pref., } \\
\text { Hebei Prov.) }\end{array}$ & $\mathrm{N} 40.18000^{\circ} \mathrm{E} 117.95861^{\circ}$ \\
\hline 04 & Датунь & $\begin{array}{l}\text { Santunying Town (Qianxi County, Tangshan } \\
\text { Pref., Hebei Prov.) }\end{array}$ & $\mathrm{N} 40.22167^{\circ} \mathrm{E} 118.20250^{\circ}$ \\
\hline 05 & Ланьхэ & $\begin{array}{l}\text { Luan River (Inner Mongolia and Hebei } \\
\text { Provs; flow into Bohai Sea) }\end{array}$ & - \\
\hline 06 & Цзунь-хуа-чже & Chengde prefecture-level city (Hebei Prov.) & $\mathrm{N} 40.96778^{\circ} \mathrm{E} 117.93611^{\circ}$ \\
\hline 07 & Хан-го-тунь & $\begin{array}{c}\text { Longhua county-level city (Chengde Pref., } \\
\text { Hebei Prov.) }\end{array}$ & $\mathrm{N} 41.32056^{\circ} \mathrm{E} 117.73583^{\circ}$ \\
\hline 08 & Исухэ & $\begin{array}{c}\text { Yixun River (Hebei Prov.; Luan River } \\
\text { tributary) }\end{array}$ & - \\
\hline 09 & Ляохаэ & $\begin{array}{l}\text { Laoha River (Hebei, Inner Mongolia and } \\
\text { Liaoning Provs; flow into Bohai Sea) }\end{array}$ & - \\
\hline 10 & Ляофу & $\begin{array}{c}\text { Laofu Town (Songshan District, Chifeng } \\
\text { Pref., Inner Mongolia Prov.) }\end{array}$ & $\mathrm{N} 42.17944^{\circ} \mathrm{E} 118.25361^{\circ}$ \\
\hline - & Ихэчуань & $\begin{array}{c}\text { Yinhe (= Xar Moron) River (Inner } \\
\text { Mongolia Prov.; Laoha River tributary) }\end{array}$ & - \\
\hline 11 & Монгуинцза & $\begin{array}{l}\text { Mengkeying Zi (Songshan District, Chifeng } \\
\text { Pref., Inner Mongolia Prov.) }\end{array}$ & $\mathrm{N} 42.29474^{\circ} \mathrm{E} 118.16637^{\circ}$ \\
\hline 12 & $?$ & $\begin{array}{l}\text { Shanwanzixiang Town (Songshan District, } \\
\text { Chifeng Pref., Inner Mongolia Prov.) }\end{array}$ & $\mathrm{N} 42.38900^{\circ} \mathrm{E} 117.81998^{\circ}$ \\
\hline 13 & Тунцзя-инцзя & $\begin{array}{l}\text { Tongjia Yingzi (Songshan District, Chifeng } \\
\text { Pref., Inner Mongolia Prov.) }\end{array}$ & $\mathrm{N} 42.46700^{\circ} \mathrm{E} 117.70300^{\circ}$ \\
\hline
\end{tabular}

Notes: "nn" — numbers correspond to geographic names in the text and figs 1-2; "Pref." — Prefecture; "Prov." — Province; "?" — locality is not mentioned in the text of Putjata's diary. 


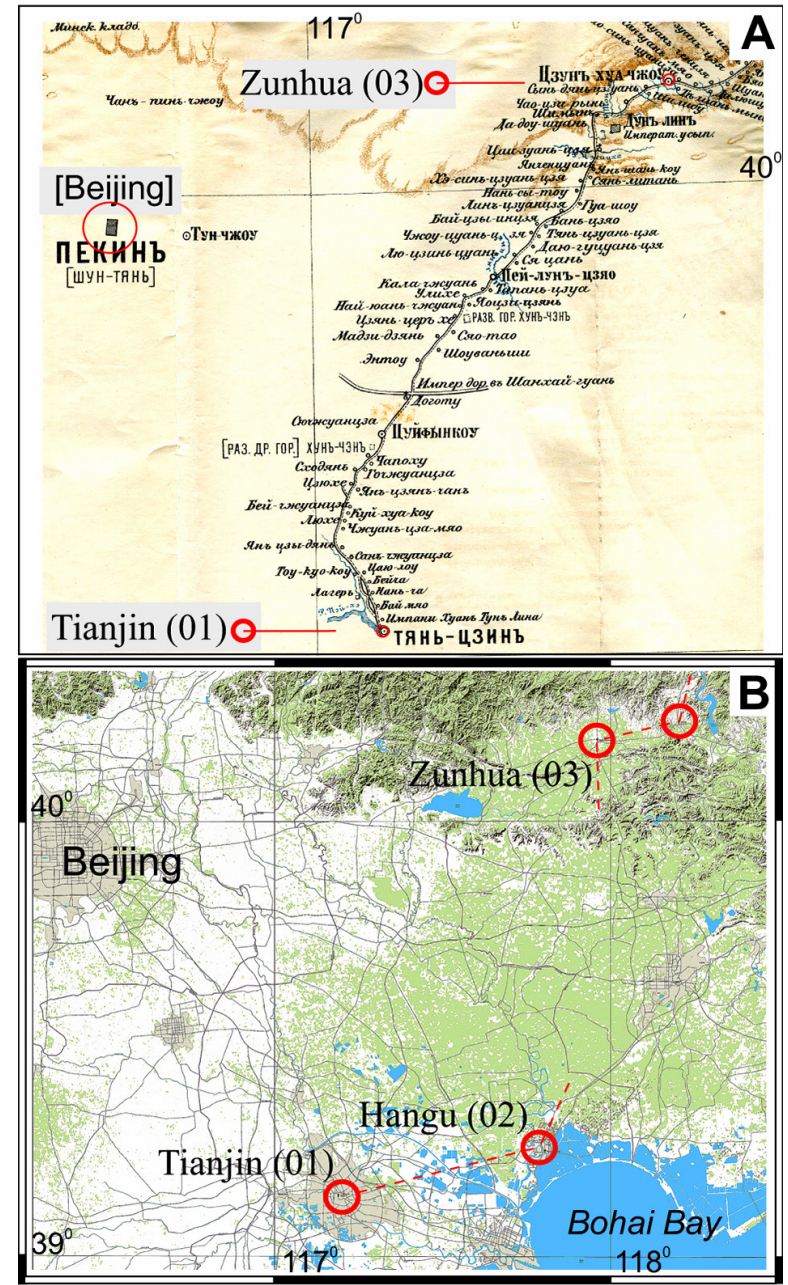

Figure 1. The first part of Putjata's route of the Khingan expedition of 1891. A. Part of the original map from the published diary of the expedition; B. Modern map of the Chinese territory. Abbreviations: red rings (map A) - the determined locations from Putjata's map (modern names of the locations taken from https://www.google.ru/maps); red rings with dotted line (map B) - route points associated with Putjata's map, and route direction ("Hangu" included from diary text); numbers in parentheses - see in Table 1.

The Khingan expedition started on May 5th, 1891 in Tianjin City (01, see Tab. 1). Dmitry V. Putjata and his companions moved north-east through Hangu (02) and further to the north through Zunhua (03), where they entered the southern branches of the Yin Mountains. After visiting Zunhua, they turned east and reached Santunying (04), and after that travelers moved north along the Luan River (05) to Chengde (06). After Chengde, the expedition moved to Longhua (07), and further to the north along the Yixun River (08) to a mountain pass between Luan and Laoha (09) river basins (Fig. 2). The travelers passed the northern branches of the Pingdingshan Ridge to ones of the Laoha River tributary (the upper part of the river bears the name "Shelusha" according
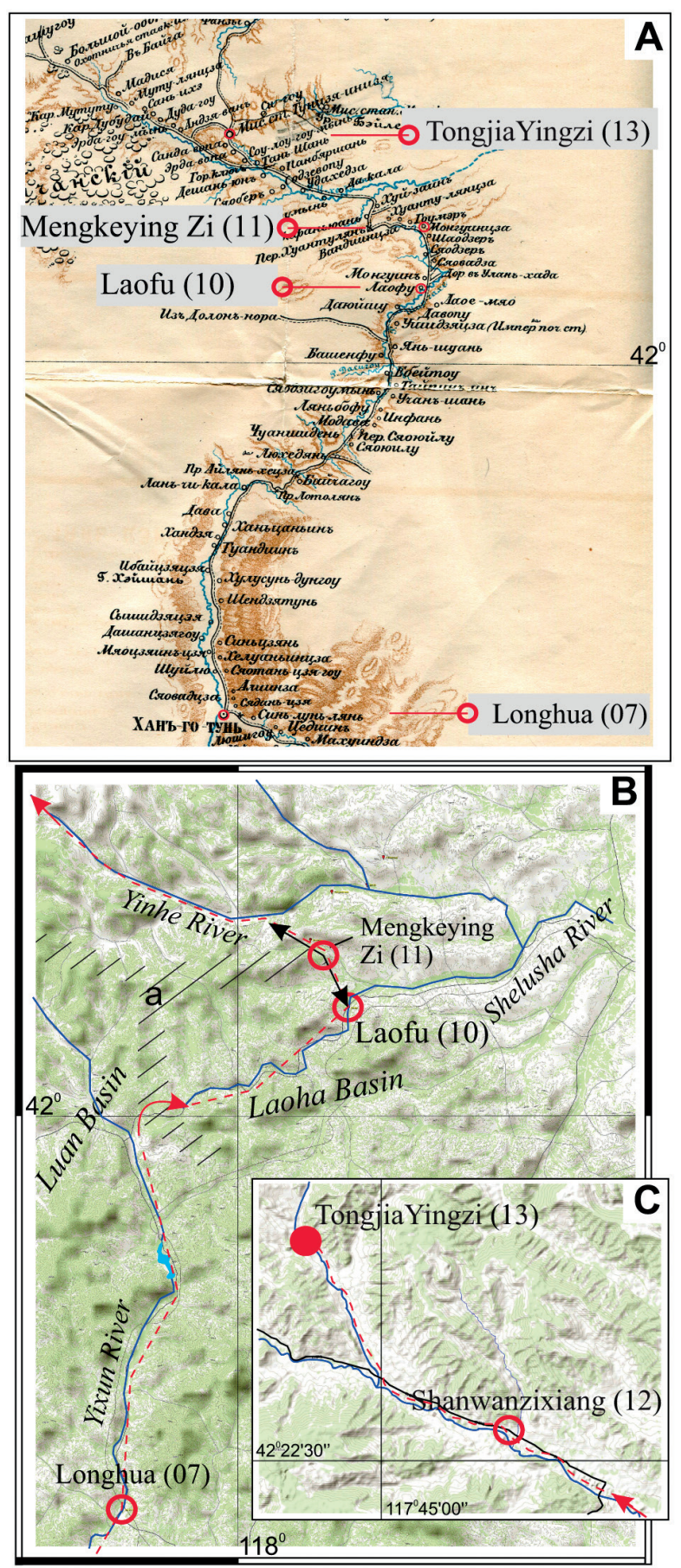

Figure 2. The next part of Putjata's route with point "Missionary Station Tongjia Yingzi". A. Part of the original map; B. Modern map; C. Magnified modern map. Abbreviations: a - approximate area (hatched) of the mountain pass between Luan and Laoha River basins; black line with arrows - parts of the route with its length $(\mathrm{km})$ between Laofu and the Yinhe River valley, which are mentioned in the diary; red arrow direction of travel from Luan River basin to Laoha River basin; also see Fig. 1. 
Предложивъ моимъ спутникамъ остаться въ Тунцзя-инцзъ для А

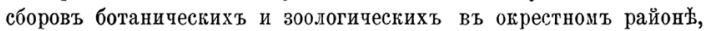
я выступиль 12/24 іюня въ сопровожденіи казака Жаркого, ки-

Слґдуя вверхъ по долинङ, минуя на каждомъ шагу значительныя деревни, мы достигли 16 іюля д. Гуапундянъ, гд'ъ им'ли первый ночлегъ въ передній путь и откуда дорогой раньше пройденной я на другой день присоединился къ своимъ спутникам въ Тунцзя-Инцзљ, которыхъ засталь въ добромъ здоровьи и обогащенныхъ пріобрытеніями для ғоллекцій по зоологіи и ботаник'

Figure 3. Two fragments of the diary text with mention of zoological specimen collection around "Missionary Station Tongjia Yingzi": A - p. 21; B - p. 43. Translation A: "Inviting my companions to stay in Tongjia Yingzi for botanical and zoological collecting in the surrounding area, I left June 12th accompanied by a kazak Zharky, ...". Translation B: "Following up the valley, bypassing at every step large villages, we reached the village of Guashundjang in July 16th, where we had our first night on the first road $<$ from Tongiia Yingzi> and from where I had traveled the previous day I joined my companions in Tongjia Yingzi, who were in good health and enriched by acquisitions for collections of zoology and botany".

to GoogleMaps) and moved to Laofu (10). After this place, Putjata's expedition moved north-west through a small ridge (11) to the valley of the Yinhe River and then moved upwards along its, approximately to the area of modern Shanwanzixiang Town (12).

According to coordinates from the Putjata's map, Tongjia Yingzi (13) situates in the valley of a left tributary of the Yinhe River approximately seven kilometers from the place of a mouth. Also, this place situated as far as about $13 \mathrm{~km}$ from Shanwanzixiang (Fig. 2). There is additional information on Tongjia Yingzi village presents in the diary: it was a place of Belgian Missionary Station location. Catholic priest Pere de Beule was an abbot of this station during the period of fieldwork of Putjata's expedition, while monks helped travelers with a collection of zoological and botanical specimens (Putjata, 1893: 20-21) (Fig. 3).

Therefore, the terra typica of mammalian taxa, which are described from the Putjata's collection, should be associated with a vicinity of modern Tongjia Yingzi Village situated at $\mathrm{N} 42.467^{\circ} \mathrm{E} 117.703^{\circ}$.

\section{A checklist of the collected mammals}

The checklist given below is based on specimen's labels, inventory books, and records in the catalog of the Laboratory of Theriology of the Zoological Institute of the Russian Academy of Sciences. The zoological specimens from the Khingan expedition of 1891 are not numerous. Travelers collected most specimens around the settlement Tongjia Yingzi, as described in the diary (Putjata, 1893: 21, 43; see Fig. 3). Two specimens, Erinaceus chinensis Satunin, 1907 and Parascaptor grandidens Stroganov, 1941, were described as new species (Satunin, 1907; Stroganov, 1941) and were published in the catalog of the type specimens (Baranova et al.,
1981). Other specimens were stored in a dry condition or preserved in alcohol with previous species determination, as follows:

\section{Order: Lipotyphla Haeckel, 1866 \\ Family: Erinaceidae Fischer, 1817}

Erinaceus amurensis Schrenck, 1859 - Amur hedgehog $(n=1)$

ZIN 7557 (Fig. 4) - holotype of Erinaceus chinensis Satunin, 1907 (Satunin, 1907: 173); body in ethanol, skull extracted; sex unknown, immature (subadultus); collected 06/1891, collector from Putjata expedition, no exact name on the label; Tongjia Yingzi (= Тунзцяинцза; circa N42.467 ${ }^{\circ}$ E117.703 ${ }^{\circ}$ ), Shanwanzixiang Town vicinity, Chifeng Prefecture, Inner Mongolia, China.

Previous identification: Before Alexey A. Gureev, an unknown zoologist (probably Sergey I. Ognev) associated the holotype with Erinaceus dealbatus Swinhoe, 1870. Alexey A. Gureev (Baranova et al., 1981: 4) re-determined the holotype as Erinaceus europaeus amurensis.

Remarks: The skull and dentary are moderately corroded by low-quality preservation liquids (ethanol and/or formaldehyde); the right ear structures (ectotympanic, ossicles) are lost; lateral parts of the tympanic process of the basisphenoid are damaged; tips of the paroccipital process are damaged; both dentaries are separated; the dp4 and p4 are present on both dentaries, and $\mathrm{p} 4$ shifted buccally from its normal position. The individuals age is re-defined as immature by us (Alexey A. Gureev identified it as adultus) because of the stage of tooth wear, the interval between the lateral part of the postpalatine torus and posterior edge of M3 alveolus, and the presence of milk dp4 in the lower tooth row (aberrant character), and this corresponds to the second relative age group, subadult animals (see Voyta, 2017). CBL $=56.40 \mathrm{~mm} ; \mathrm{MRH}=19.60 \mathrm{~mm}$.

\section{Family: Talpidae Fischer, 1817}

Scaptochirus moschatus Milne-Edwards, 1867 — Shortfaced mole $(n=1)$

ZIN 6372 (Fig. 5) - holotype of Parascaptor grandidens Stroganov, 1941 (Stroganov, 1941: 270); skull extracted; female, mature (adultus); collected 06/1891, collector from Putjata expedition, no exact name on the label (see Amur hedgehog), Tongjia Yingzi (= Тунзця-Инцза), ibid.

Previous identification: The first label was "Talpa lepture”. Before Sergey U. Stroganov's new species description, an unknown zoologist (probably Sergey I. Ognev) identified specimens as $S$. moschatus (see Fig. 5, face of the specimen label); Alexey A. Gureev (Baranova et al., 1981: 6) accepted Stroganov's identification of $P$. grandidens. 


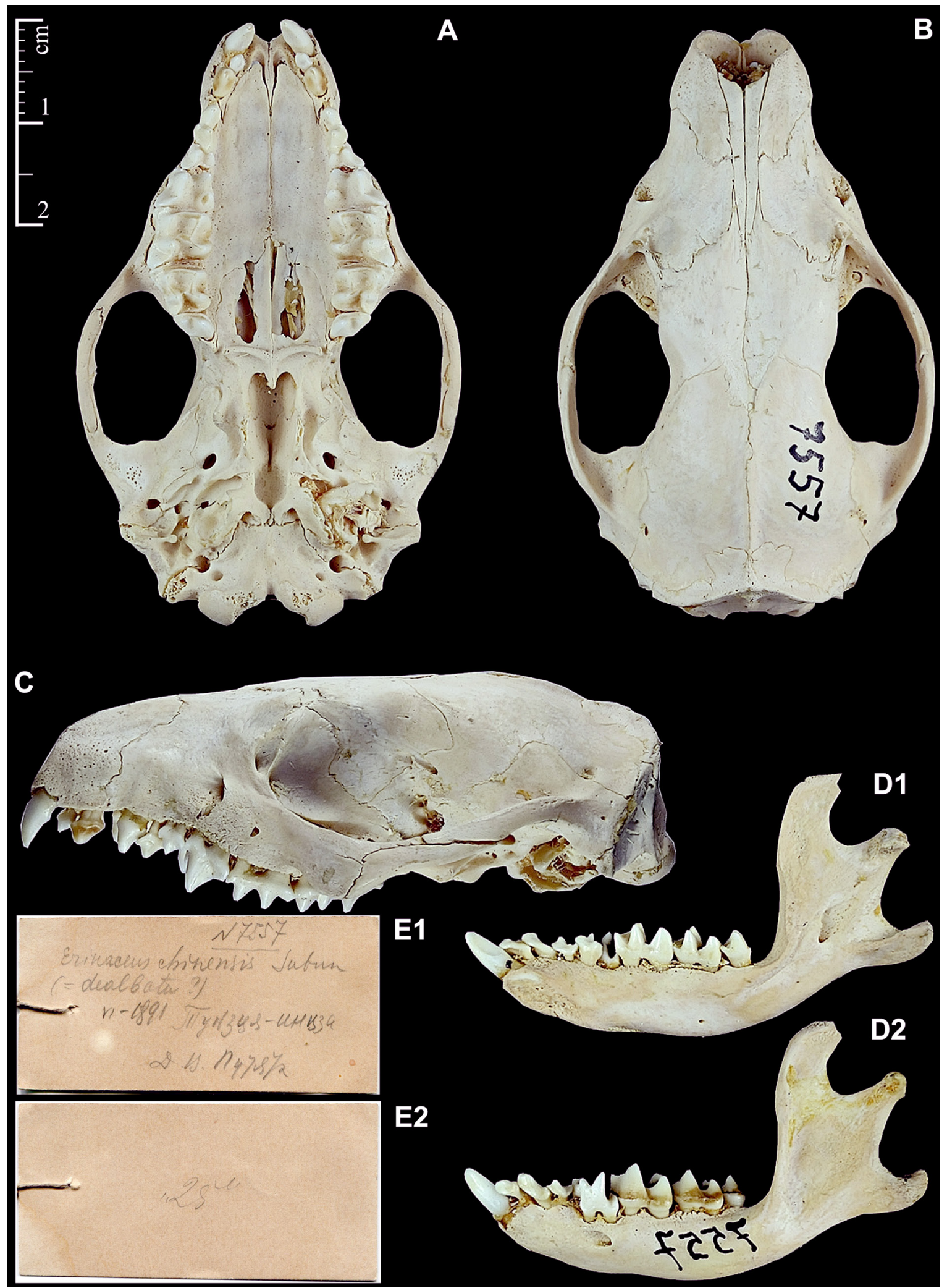

Figure 4. Holotype of Erinaceus chinensis Satunin, 1907 (ZIN 7557; = Erinaceus amurensis): A — ventral view of skull; B - dorsal view; C - lateral view; D - dentaries (D1 - medial view; D2 - lateral view); E - original label (E1 - front view; E2 - rear view; unscaled). Scale $=2 \mathrm{~cm}$. Notes: E1 — [N7557] [Erinaceus chinensis Satun] [(= dealbatus ?)] [VI-1891 Тунзця-инцза] [Д.И. Путята]; Е2 - ["28"]. 




Figure 5. Holotype of Parascaptor grandidens Stroganov, 1941 (ZIN 6372; = Scaptochirus moschatus). Abbreviations: see Fig. 4. Notes: E1 — [N6372] [Scaptochirus moschatus] [о ad.] [Китай, Ю-В. Монголия] [4136] [Тунзця-Инцза Хинганск. эксп.] [Путяты]; Е2 — [Typus!] [Parascaptor grandidens sp. n.] [2.III-1941.] [det. S. Stroganov]. 
Remarks: The right tympanic capsule was cut by Sergey U. Stroganov, cap of the capsule (ectotympanic) and ossicles are lost; both dentaries are separated. SCL $=$ $31.50 \mathrm{~mm}$; $\mathrm{MRH}=6.70 \mathrm{~mm}$.

Order: Chiroptera Blumenbach, 1779

Family: Vespertilionidae Gray, 1821

Myotis blythii Tomes, 1857 — Lesser mouse-eared myotis $(n=3)$

ZIN 5190 — body in ethanol; collected 06/1891, a collector from Putjata expedition, no exact name on the label (see Amur hedgehog), Tongjia Yingzi (= Тунцзя-инцза), ibid.

ZIN 5191 - skull extracted; male, mature (adultus); collected 06/1891, a collector from Putjata expedition, no exact name on the label (see Amur hedgehog), Tongjia Yingzi (= Тунцзя-инцза), ibid.

ZIN 5192 - skull extracted; male, mature (adultus); collected 06/1891, a collector from Putjata expedition, no exact name on the label (see Amur hedgehog), Tongjia Yingzi (= Тунцзя-инцза), ibid.

Previous identification: The first label was "Vespertilio daubenthoni". All three specimens were re-determined as M. blythii by Petr P. Strelkov.

Remarks: ZIN 5191 - the left zygomatic arch is damaged; $\mathrm{SCL}=22.80 \mathrm{~mm}$; $\mathrm{MRH}=5.25 \mathrm{~mm}$. ZIN 5192 $-\mathrm{SCL}=23.00 \mathrm{~mm} ; \mathrm{MRH}=5.60 \mathrm{~mm}$.

Plecotus auritus Linnaeus, 1758 - Brown long-eared bat $(n=4)$

ZIN 5189 - body in ethanol, skull extracted; sex unknown, mature (adultus); collected 06/1891, a collector from Putjata expedition, no exact name on the label (see Amur hedgehog), Tongjia Yingzi (= Тунцзя-Инцза), ibid.

ZIN 5186-5188 - body in ethanol; collected 06/1891, a collector from Putjata expedition, no exact name on the label (see Amur hedgehog), Tongjia Yingzi (= Тунцзя-Инцза), ibid.

Species identification: The first label was "Plecotus auritus"; this determination was confirmed by Petr P. Strelkov.

Remarks: ZIN 5189 - the posterior part of skull is heavily damaged; both dentaries are separated and damaged (anterior teeth are absent, mandibular ramus damaged).

Order: Rodentia Bowdich, 1821 Family: Sciuridae Fischer, 1817

Tamias sibiricus (Laxmann, 1769) — Siberian chipmunk $(n=2)$

ZIN 3876 (Fig. 6) - skull extracted, skin extracted and stuffed; sex unknown, mature (adultus); collected 07/1891, a collector from Putjata expedition, no exact name on the label (see Amur hedgehog), Tongjia Yingzi (= Тунзця-Инцза), ibid.
ZIN 3878 - ibid.

Species identification: The first label was "Eutamias asiaticus".

Remarks: ZIN 3876 - the right zygomatic arch is damaged; both dentaries are separated and damaged (the angular process of the left dentary is broken; the angular and coronoid processes of the right ones are broken also); $\mathrm{SCL}=41.60 \mathrm{~mm}$; $\mathrm{MRH}=12.30 \mathrm{~mm}$. ZIN 3878 - the posterior part of the skull is heavily damaged; the right zygomatic arch is damaged; the right lower third molar is lost; the angular process of the left dentary is partly damaged; $\mathrm{MRH}=11.50 \mathrm{~mm}$.

Spermophilus dauricus Brandt, 1843 - Daurian ground squirrel $(n=4)$

ZIN 6924 (Fig. 7) - skull extracted; sex unknown, mature (adultus); collected 06/1891, a collector from Putjata expedition, no exact name on the label (see Amur hedgehog), Tongjia Yingzi (= Тунцзяиндзя), ibid.

ZIN 6925-6927 — body in ethanol; collected 06/1891, a collector from Putjata expedition, no exact name on the label (see Amur hedgehog), Tongjia Yingzi (= Тунцзя-индзя), ibid.

Species identification: The first label was "Spermophilus mongolicus". Unknown scientist wrote on label "Citellus mongolicus".

Remarks: ZIN 6924 - the left pterygoid (hamulus) is broken-off; left dentary is lost. SCL $=43.85 \mathrm{~mm}$; $\mathrm{MRH}=13.20 \mathrm{~mm}$

\section{Family: Muridae Illiger, 1811}

Mus musculus Linnaeus, 1758 - House mouse $(n=1)$

ZIN 52703 (Incoming ID 19-1921) (Fig. 8) — body with a skull in ethanol, skin extracted and stuffed; sex unknown, mature (adultus); collected 06/1891, a collector from Putjata expedition, no exact name on the label (see Amur hedgehog), China, Khingan.

Species identification: The first label was "Mus musculus".

Remarks: Body dimensions from label: $\mathrm{HB}=63.80 \mathrm{~mm}$; $\mathrm{TL}=58.10 \mathrm{~mm} ; \mathrm{HL}=14.00 \mathrm{~mm} ; \mathrm{EL}=10.00 \mathrm{~mm}$.

\section{Family: Cricetidae Fischer, 1817}

Lasiopodomys mandarinus (Milne-Edwards, 1871) Mandarin vole $(n=1)$

ZIN 104927 (Fig. 9) — skull extracted; sex unknown, mature (adultus); collected 06/1891, a collector from Putjata expedition, no exact name on the label (see Amur hedgehog), Tongjia Yingzi (= Тунцзя-индзя), ibid.

Species identification: The first label was "Microtus sp. ?".

Remarks: The skull and dentary are moderately corroded by low-quality preservation liquids; left tympanic 


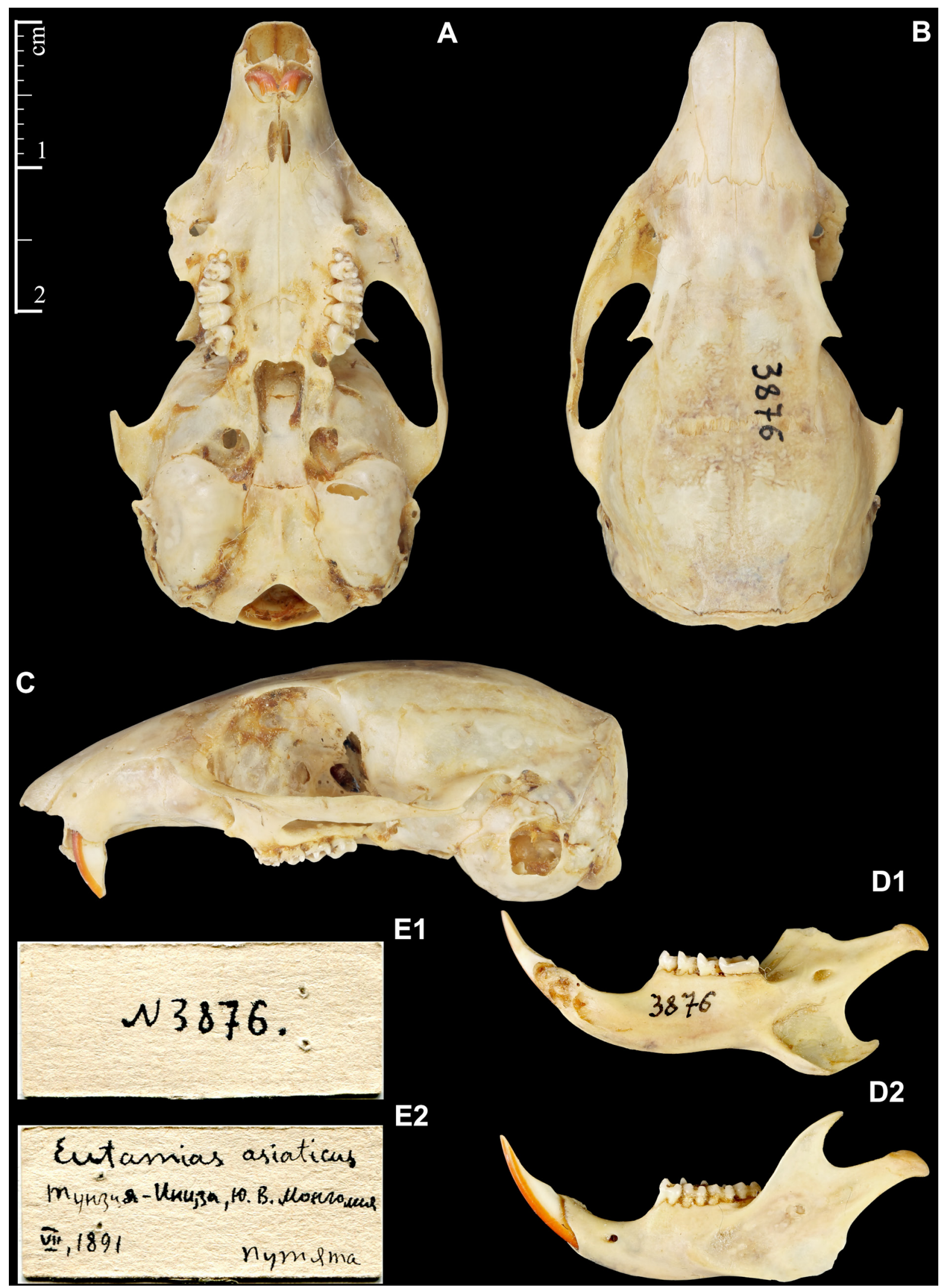

Figure 6. Specimen of Tamias sibiricus (Laxmann, 1769) (ZIN 3876). Abbreviations see in Fig. 4. Notes: E1 — [N3876]; E2 — [Eutamias sibiricus] [Тунзця-Инцза, Ю. В. Монголия] [VII, 1891] [Путята]. 


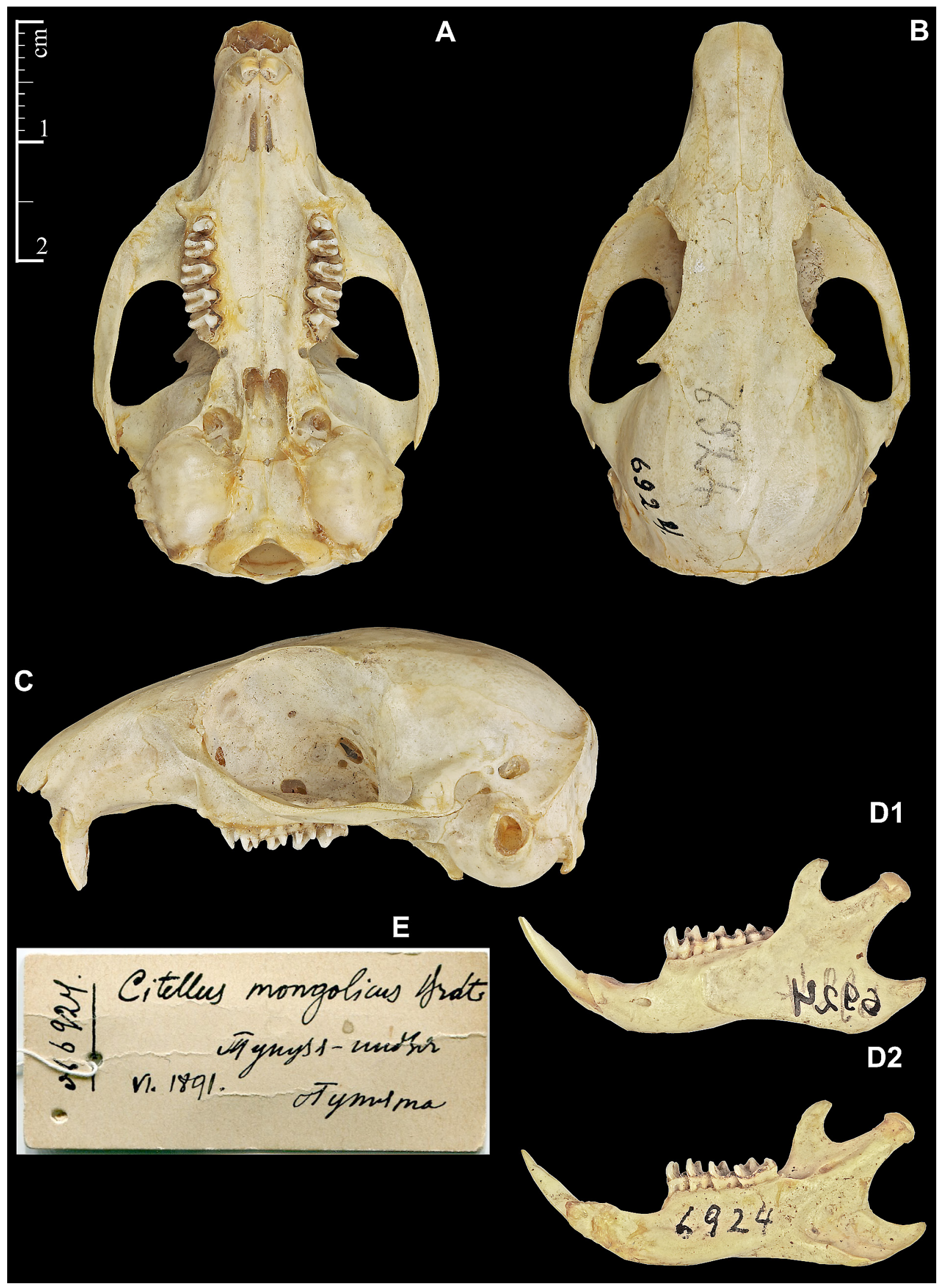

Figure 7. The specimen of Spermophilus dauricus Brandt, 1843 (ZIN 6924). C - lateral, mirror-reflected view of the skull; D1 - medial, of mirror-reflected view of the right dentary; D2 - lateral view of right dentary; E - original label (unscaled); also see in Fig. 4. Notes: E — [N6924] [Citellus mongolicus Brdt] [Тунцья-индзя] [VI. 1891.] [Путята]. 


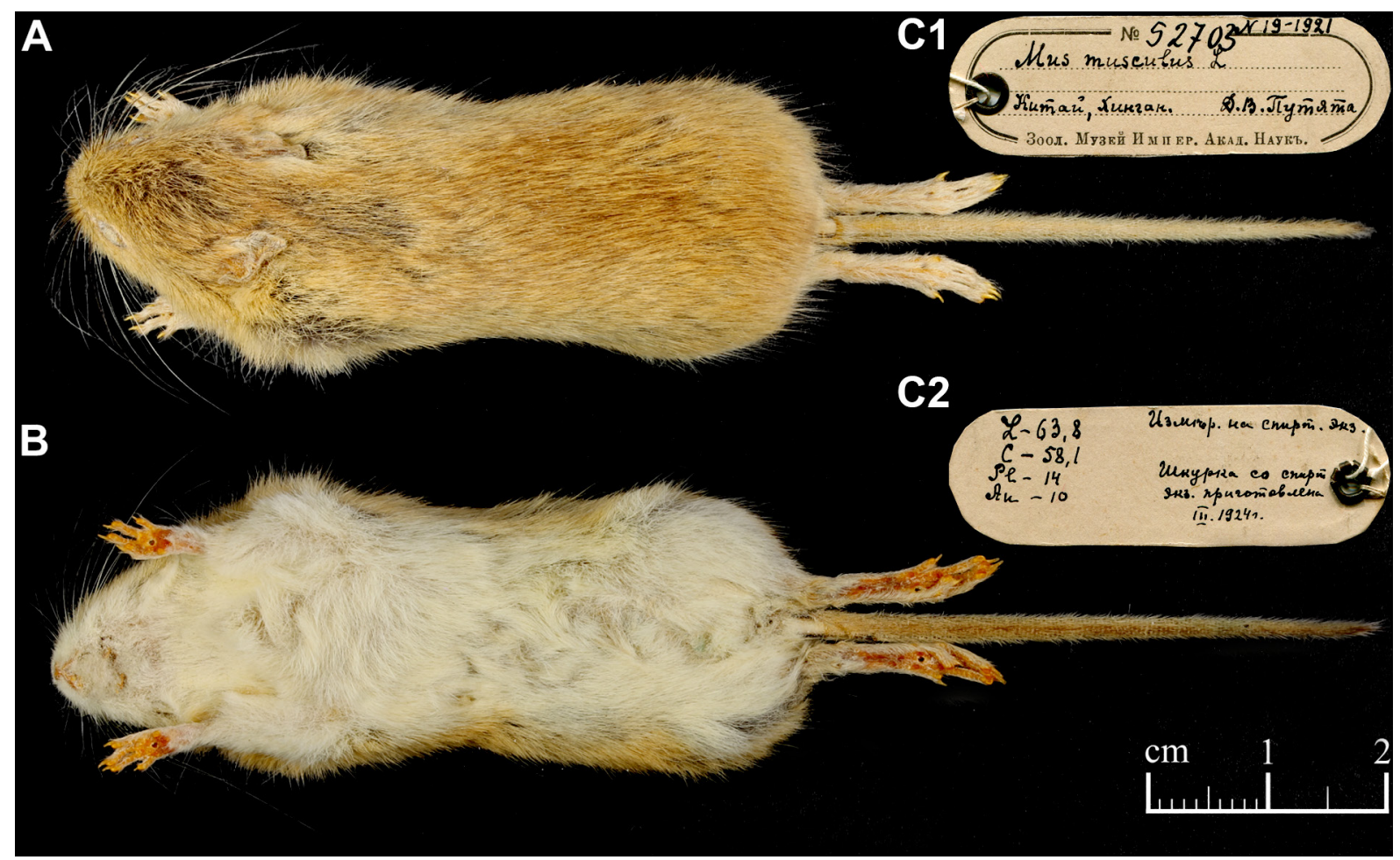

Figure 8. The specimen of Mus musculus Linnaeus, 1758 (ZIN 52703). A — dorsal view of stuffed skin; B — ventral view; $\mathrm{C}$ - original label $(\mathrm{C} 1$ - face side; $\mathrm{C} 2-$ back side; unscaled). Scale $=2 \mathrm{~cm}$. Notes: $\mathrm{C} 1-[\mathrm{N} 52703]$ [N 19-1921] [Mus musculus L] [Китай, Хинган.] [Д.В. Путята] [Зоол. Музей Импер. Акад. Наукъ.]; C2 — [L - 63,8] [Измер. на спирт. экз.] [C - 58,1] [Pl - 14] [Шкурка со спирт экз. приготовлена III.1924 г.] [Au - 10].

bullae slightly damaged. $\mathrm{SCL}=23.90 \mathrm{~mm} ; \mathrm{MRH}$ $=7.90 \mathrm{~mm}$.

\section{Conclusions}

In total, 17 specimens of small mammals from Putjata's Khingan expedition are kept in the collection of the Zoological Institute of the Russian Academy of Sciences. These specimens belong to six families of the orders Lipotyphla (Erinaceidae: Erinaceus; Talpidae: Scaptochirus), Chiroptera (Vespertilionidae: Myotis, Plecotus), and Rodentia (Sciuridae: Sciurus, Tamias, Spermophilus; Muridae: Mus; Cricetidae: Lasiopodomys), which were collected d around the Belgian Missionary Station in the modern settlement Tongjia Yingzi.

ACKNOWLEDGMENTS. This study was conducted within the framework of the Federal themes of the Theriology Laboratory of ZIN RAS "Phylogeny, morphology and systematics of placental mammals". The study was conducted under the Federal Agency for Scientific Organizations program for supporting bioresource collections and was partly financed by the Russian Foundation for Basic Research, projects no. 15-29-02457 (georeferencing research), no. 19-04-00557 and no. 1804-00327 (zoological research). We express our thanks to Dr. Andrey Lissovsky (ZMMU) for providing the
Chinese place names reported here and technical support of our investigation.

\section{References}

Baranova G.I., Gureev A.A. \& Strelkov P.P. 1981. [The catalogue of type specimens of collection of the Zoological Institute of AS USSR. Mammals (Mammalia): Insectivorous (Insectivora), Chiropterans (Chiroptera), Lagomorphs (Lagomorpha)]. Leningrad: Izdatel'stvo Nauka. 24 p. [in Russian].

Kozlov P.K. 1948. [Mongolia and Amdo and the dead town Khara-Khoto]. Moskva: Izdatel'stvo Geografgiz. 328 p. [in Russian].

Przhevalsky N.M. 1897. [The travels of N.M. Przhevalsky in East and Central Asia]. Sankt-Peterburg: Knigoizdatel'stvo A.F. Devrienta. 304 p. [in Russian].

Putjata P.K. 1893. [The Khinganian expedition of 1891. The route description (with map)]. Sankt-Peterburg: Voennaja Tipographia. 83 p. [in Russian].

Satunin K. 1907. Über neue und wenig bekannte Igel des Zoologischen Museums der Kaiserlichen Akademie der Wissenschaften zu St. Petersburg // Annuaire du Musée Zoologiue de L'Académie Impériale des Sciences de St.-Pétersbourg. Vol.11. P.167-190.

Strauch A.A. 1889. [Zoological museum of Imperial Academy of Sciences: 50 years of its existence (The review of its foundation, gradual expansion and modern state of the 




Figure 9. The specimen of Lasiopodomys mandarinus (Milne-Edwards, 1871) (ZIN 104927). D — dentaries; also see in Fig. 4. Notes: E1 — [Microtus sp.?] [1981 г.] [Тунзця-Инцзя.] [Д.В. Путята] [(№29-30)]; Е2 — [Д.В. Путята] [N 29-30.] [Тунзцяинцзя 91 г.].

museum)] // Zapiski Imperatorskoi Akademii Nauk. Vol.61. No.3. P.1-372 [in Russian].

Stroganov S.U. 1941. [The insectivore mammals of USSR Fauna] // Doklady Akademii Nauk SSSR. Vol.33. P.270-272 [in Russian].
Voyta L.L. 2017. Age related cranial characters from the viewpoint of species identification of Amur and Daurian hedgehogs (Lipotyphla: Erinaceidae) // Russian Journal of Theriology. Vol.16. P.176-184. 